\section{E-LOGOS}

ELECTRONIC JOURNAL FOR PHILOSOPHY ISSN 1211-0442

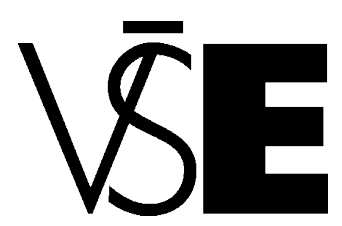

University of Economics Prague

\title{
What does Marx mean by the "fetishism of commodities"?
}

Alexandra Dobra

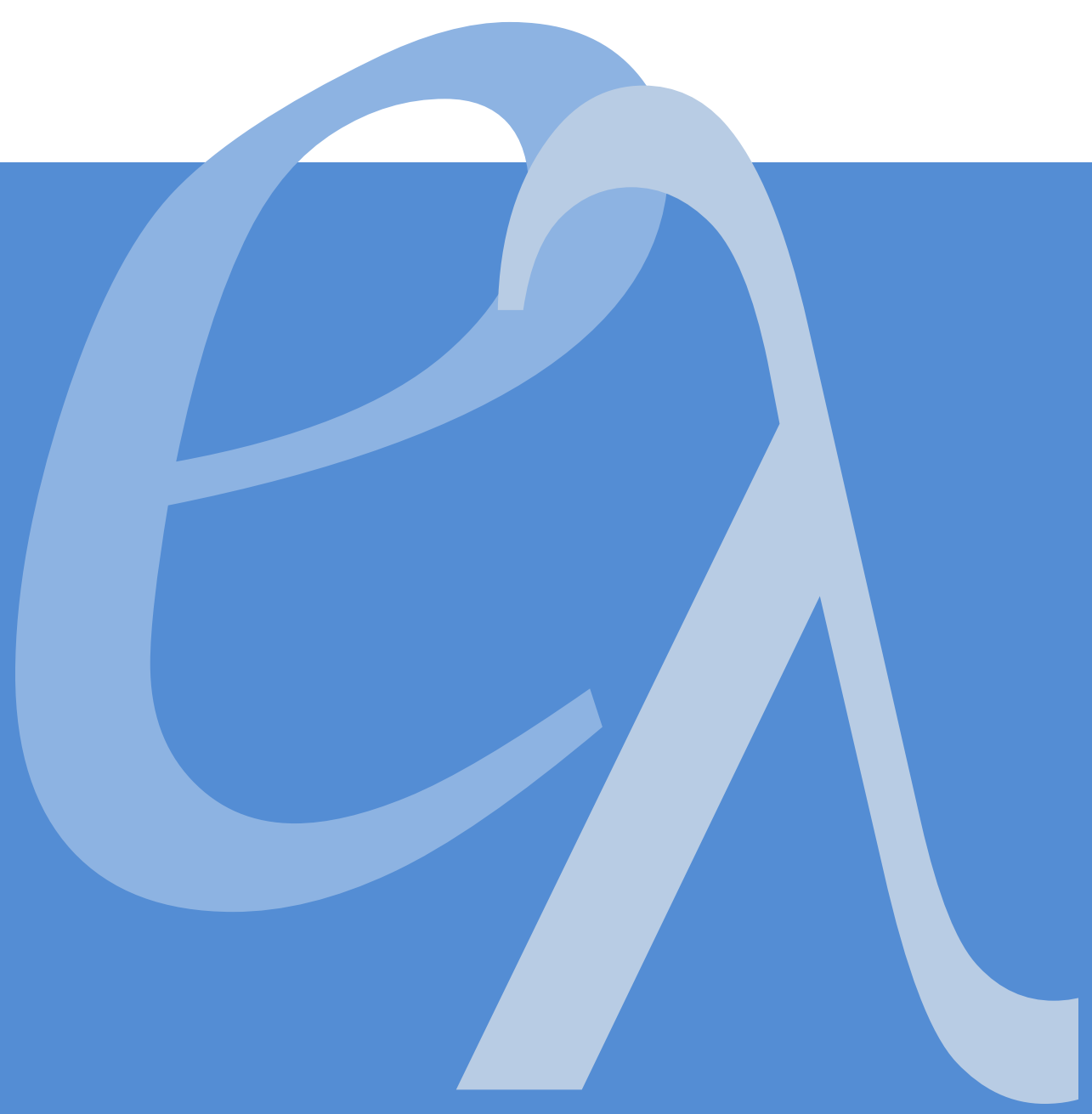




\begin{abstract}
The present paper aims to analyse Marx's concept of "fetishism of commodities" by explaining the mechanism of a social genesis of determined illusions, arising in the sphere of production and circulation of commodities. It highlights the existence of an auto-sustained autarkic system of 4 variables - reification, objectification, duplicity and habit - sustaining and leading to the fetishism of commodities.
\end{abstract}

Keywords: Marx, Fetishism; Commodities; Social Relations; Reification; Duplication. 


\title{
Introduction
}

\author{
"The components of human society are not the \\ Humans but the relations existing between them."
}

Toynbee

In The Capital Marx uses the Feuerbachian model of reversal in order to develop his notion of fetishism of commodities. A commodity is defined as "an object outside us, a thing that by its properties satisfies human wants of some sort or another" (Marx, 1992) while fetishism is defined as attributing inherent value to an object. Commodity fetishism is the appearance that the commodity has a natural and intrinsic value, apart from the labour bestowed on it. So, the main thrust of the commodity fetishism concept is that the exchange-value (what makes something a commodity) doesn't relate in proportion to the use-value.

For Marx, the capitalist economic world is truly of religious essence, in other words, religious ideology has been replaced by market ideology. As such "human needs are realized and appear in the form of alienated essence in religion just as economic relations do in social life according to Marx" (Hamacher, 1999). The fetishism of commodities corresponds to "a definite social where relation between men assumes the fantastic form of a relation between things" (Marx, 1992).

The present paper analyses Marx's concept of "fetishism of commodities" by explaining how an illusory representation can produce tangible effects and contribute to the production of a specific economy and society.

"The mutual relations of the producers take the form of a social relation between products."

(Marx, 1992)

Under capitalism the social relations of production are established by means of the transfer of "things" from individual to individual. This transfer of things has a coercive power over men via the way production is organized. Commodity fetishism describes a situation in which alienation predominates, due to "the social power which arises through the co-operation of different individuals appears to these individuals not as their own united power, but as an alien force existing outside them, of the origin and goal of which they are ignorant, which they thus cannot control" (Marx, 1992). In capitalism the domination of the "material" is not an illusory interpretation of social relations among people, it is a real social fact, 
fetishism is "a phenomenon of social being" (Rubin, 1972). In other words, "property, capital, money, wage labour, do not in themselves represent phantoms of the imagination, but very practical, very concrete products of self-alienated forms of two worlds".

The fetishist character of the commodity consists in a symmetrical phenomenon of reification and deification. Reification corresponds to what as an exchange value becomes alienated from the human (Adorno, 2002). It is the confusion of social relations with their material support to objects - commodities and signs in which and through which relations of productions are materialized and signified. It is a fixation opposed to the open realization of the fluctuating and changing nature of life (e.g. : individual is reduced to a wage). In turn, deification corresponds to a supra-human personalization leading to attribute substantially to objects qualities and proprieties. At the heart of fetishism lies the reversal between the subjective and the objective. There is a reificatory objectification of subjects (of human relations and practices) and a deificatory subjectification of the object which institutes the reversal of the world (reverberated in capitalism) in which commodities command humans. The capacity of exchanging commodities is no longer the result of a common identity of products of labour, but the result of a mysterious internal characteristic, that they possess in a substantial manner, the value.

"A commodity is a mysterious thing because in it the social character of men's labour appears to them as an objective character."

(Marx, 1992)

At the level of its content, fetishism denotes a functional lack of dialectics because it is the result of a human operation insulating, hypostatizing and therefore absolutizing elements of the real. Fetishization is thus a constitutive form of socialization. "The commodity's objectivity becomes the model of every objectivity" (Balibar, 2001), and this objectification extends to all human activities. There is a domination of the form value, of the abstraction and ultimately of the commodity. The development of exchange of objects on a marketplace brings humans into novel kinds of relationships. When objects are produced to be commodities, they possess an exchange value, which is a ratio of equivalence to other commodities. As this development of exchange increases, exchange-value loses its arbitrary nature and becomes a social phenomenon, a value inherent in the object it signifies. Commodity "transcends sensuousness" (commodity is fetish because it appears as possessing qualities beyond its own structure). The table steps forth as a commodity and is changed into something transcendent. Hence, "the subject realizes itself through a 
consideration of external objects, a recursive process, as object and subject act upon each other" (Miller, 1987). Objects become active agents in the construction of society.

The commodity appropriates itself the integrality of the labour's social power by making it appear as its own power. The commodity seems to assume by its process of circulation, by the intertwining of the multiple atomized fragments, the unity in space and time of the process of production. There is a process of subversion, of transmutation; relations between humans cover the form of relations between objects. There is an illusion of the human conscience having its roots in the trade economy, which attributes to commodities, characteristics having the origins in the social relations between humans during the production process. The illusion and error in the human spirit transforms economic categories in "forms of the intellect having an objective truth" (Marx, 1992).

Labour becomes distorted and the product of labour "appears to these individuals not as their united power, but as an alien force existing outside them, of the origin and goal of which they are ignorant, which they thus cannot control" (Marx, 1992). In other words, a false consciousness occurs and the product lacks a social form anterior to its manifestation as a commodity: "mystery arises because the social character of the production is expressed only in exchange, not in production itself (Marx, 1992)". Moreover, there is no integration and producers connect only mediately through exchange as marketers. Fetishism has as consequence the division between the concrete side immediately practical and the abstract side, the face proper to the exchange. When elements which must be united are abscinded, they become unified indirectly in illusory forms. A division in what needs to be unified leads to duplication, a second world arises to confer surrogate coherence to the fragmented elements. As such the social form becomes alienated from its productive content.

"The fetishism of commodities has its origin in the peculiar character of the social character of the labour that produces them."

(Marx, 1992)

"It is not consciousness that determines life but rather life determines consciousness" (Marx, 1976), it follows that the human erects in absolute reality his own vision of the world; he hypostatizes his ideas and considers them as realities. When he obeys these realities he alienates himself. In capitalist societies, members are socially disconnected, "purely atomized" (Marx, 1992), and linked only via the exchange of products. "Articles of utility become commodities, only because they are products of private individuals or groups who carry on their work independently of 
each other" (Marx, 1992). Thus individuals consider the exchange of commodities as the reality. Fetishism is an elaborated and constraining form of social illusion, of social consciousness, sustained by the permanent transposition of the socially produced abstract wealth, privately accumulated, into social relations. The fetishism of commodity is the sign of a derealisation of the social consciousness, of a desocialization. Furthermore, the created individual relation to the object and its representation - the commodity - favours narcissist attitudes (narcissism of small differences in Freud's terminology), illusory and asocial forms of love, contributing to enhance the social atomization and fetishization.

When people live within a capitalist society, their whole life is structured through commodities. They have to work in order to gain the money commodity, which then allows people to buy other commodities from others (C-M-C' scheme). So, the commodity is a "thing" and a representation entertaining the logic by which it is created. This closed relationship between production and consumption alienates people into an experience of market influenced commodities. Humans are endowed with a false consciousness - the man's labour products come to play a social determinant role - and thus become alienated by their own work. Fetishism unites the capitalist world of production and exchange to the representations and believes of individuals, which ensure the capitalist reproduction and functioning. A reversal of the world, realized by the commodity fetishism, occurs : "the economic and social reality is indeed perceived as the matrix of all human alienations" (Marx, 1988).

"Man's reflections on the forms of social life, and consequently, also his scientific analysis of those forms, take a course directly opposite to that of their actual historical development."

(Marx, 1992)

As stipulated in the ut supra parts, fetishism creates a second world. There is social construction of untruths. Hence, there is a duplicity build into the economic structure of capitalism. This duplicity implies a hidden truth image and a collective social forgetting process. The forgetting operates because habit fixes on price to commodities and the hidden secret - of the value and nature of commodity disappears from awareness. Hence, the accomplishment of social customs results into a collective unconsciousness. The collective forgetting occurs because of the human desire to drive away a disturbing thought from conscious awareness (confere Freud's concept of Verdrängung). Succinctly expressed, there is a closed auto-sustained system between four variables, "fetishism", "duplicity", "habit" and "unawareness" - F-D-H-U scheme. 
The collective unawareness is also sustained by the unplanned nature of social relations. Because social relations are unplanned, knowable only à posteriori, they become visible only via the results of man's activities, the commodities. Hence, man begins with the analysis of the result of his activities. The absence of regulation of the social process directly leads to the indirect regulation of the production process via the market, via the products of labour. So, forgetting is not just the resulting expression of the routine, but does also appear to be socially motivated. Under the capitalistic specific stage of development, human relations established in the social production and reproduction can be known to them only after the event and even then only in the opposed inverted form of the relations between things : "imaginary expressions, arise however, from the relations of production themselves. That in their appearance things often represent themselves in inverted forms is pretty well known in every science except political economy." (Marx, 1992).

\section{Conclusion}

To conclude, the fetishism of commodities designates the collective and individual logic of representation, in which social relations are replaced by material relations.

The concept of fetishism of commodities is especially important in Marx's theory because it constitutes a tool for the capitalist ideology. It contributes to institutionalize domination and to stabilize class antagonisms, via the alienation. "In all ideology men and their circumstances appear upside-down as in a camera obscura" (Marx, 1998). 


\section{Bibliography}

Adorno, T. (2002). Essays on music. Berkeley : University of California Press.

Balibar, E. (2001). La Philosophie de Marx. Paris : La Découverte.

Hamacher, W. (1999). A Symposium on Jacques Derrida's Specters of Marx. Michael Sprinker Eds, London : Verso.

Marx, K., (1988). The Economic and Philosophic Manuscripts of 1844 and the Communist Manifesto. New-York : Prometheus Books.

Marx, K., (1998). The German Ideology, including Theses on Feuerbach. New-York: Prometheus Books.

Miller, A., (1987). Material Culture and Mass Consumption. Oxford : Blackwell.

Rubin, I., I. (1972). Essays on Marx Theory of Value. Detroit : Black and Red. 


\section{E-LOGOS}

ELECTRONIC JOURNAL FOR PHILOSOPHY

Ročník/Year: 2010 (vychází průběžně/ published continuously)

Místo vydání/Place of edition: Praha

ISSN 1211-0442

Vydává/Publisher:

Vysoká škola ekonomická v Praze / University of Economics, Prague

nám. W. Churchilla 4

Czech Republic

13067 Praha 3

IČ: 61384399

Web: http:/ / e-logos.vse.cz

Redakce a technické informace/Editorial staff and technical information:

Miroslav Vacura

vacuram@vse.cz

Redakční rada/Board of editors:

Ladislav Benyovszky (FHS UK Praha)

Ivan Blecha (FF UP Olomouc)

Martin Hemelík (Masarykovo klasické gymnázium, ̌̌íčany u Prahy)

Angelo Marocco (Pontifical Athenaeum Regina Apostolorum, Rome)

Jozef Kelemen (FPF SU Opava)

Daniel Kroupa (ZU Plzeň)

Vladimír Kvasnička (FIIT STU Bratislava)

Jaroslav Novotný (FHS UK Praha)

Jakub Novotný (Vysoká škola polytechnická, Jihlava)

Ján Pavlík (editor-in-chief) (VŠE Praha)

Karel Pstružina (VŠE Praha) 